\title{
腎動脈および腎乳頭部における 酸性ムコ多糖と脂質含量の年齢的変化
}

$\begin{array}{lllll}\text { 井上 剛 輔* } & \text { 沢 田 皓 史* } \\ \text { 安 田 兵 衛* 吉 川 政 已* }\end{array}$

動脈硬化とくに粥状硬化の成立には，血管壁に 脂質の沈着することが必要条件であるが，その生 成機構については，現在な和十分明らかにされて いない. 1 つの可能性として，血中脂質の組織へ の沈着が古くから指摘されており，また，酸性么 コ多糖 (AMPS) やエラスチンの関与が推測され てきた。

最近, AMPSの脂質沈着に果たす役割に関連し て, 動脈壁以外の部位に拈ける脂質, とくにコレ ステロール成分とAMPSとの関係が検討されてお り，従来からの推測を支持する成績が報告されて いる. すなわち, Crouseら"やAdamsと Bayliss ${ }^{2)}$ は, 笳肉, 皮膚, 筋膜, 硬膜, 腱などの組織にお いて，加齢とともに脂質，とくにコレステロール， コレステロール・エステル含量の増加を認め, こ れらの結合組織に括ける AMPS が血管壁におけ る AMPS と類似の役割を果たしている可能性を 指摘している. また Iverius ${ }^{33}$ は，とくにデルマタ ン硫酸 (DS) がリポ蛋白と結合しやすい事実を報 告している.

われわれは, 従来から, 腎䯣質部 (乳頭部) の AMPS の加龄による変化, 打よび尿濃縮機構と の関連などにつき検討しているが，この部位にお ける AMPS と脂質との対応を検討したので報告 する.

\section{方法と材料}

1 歳から78歳に至る腎疾患を含まない急死例の 腎を東京都監察医務院より入手した。死後 $4 \sim 12$

$*$ 東京大学医学部老年病学教室
時間の症例のみを使用し，皮質と髄質，とくに乳 頭部を分離し，腎動脈については主幹部のみを使 用した. AMPS は Schiller らの方法, ウロン酸 は Discheの方法, AMPSの組成分画には Dowex $1-\mathrm{X} 2$ と畑, 永井の 2 次元電気泳動法とを利用し た. 脂質分析には, クロロホルム・メタノール抽 出後, Folch の方法により抽出精製してから, 総 コレステロールはAbellの方法, 燐脂質はBloorの 方法を用いた。

\section{結果}

腎動脈主幹部：ウロン酸含量 (AMPS) は, 加 齢とともに漸増し，脂質成分もほぼ平行して加秢 により増加した (Fig. 1,2).

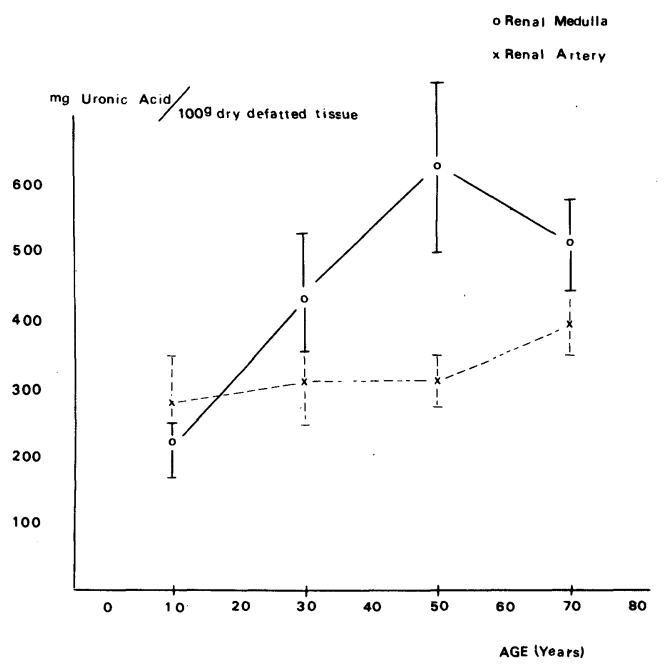

Fig. 1 


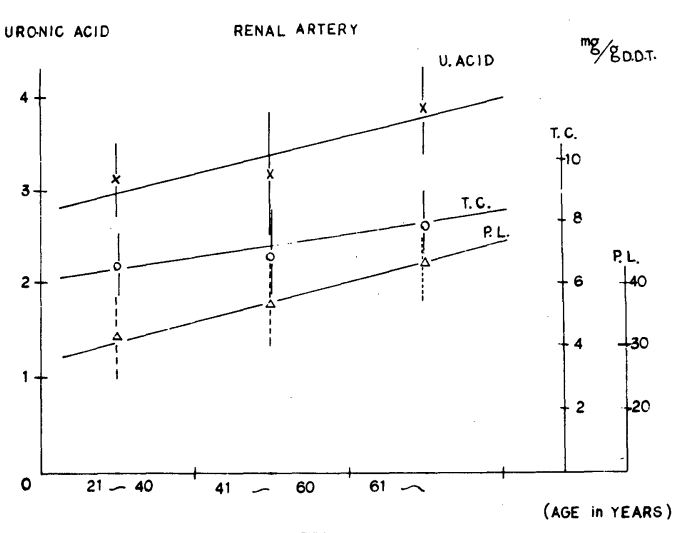

Fig. 2

腎乳頭部：AMPS は50歳代までいったん漸増 し，以後漸減する(Fig. 1)。腎皮質の AMPSは 加路とともに軽度漸増するが，髄質に比べ少な く, 皮質と乳頭部の AMPS 比は $1: 5$ から $1: 10$ に達する。

一方脂質の含量を総コレステロール含量でみる と，皮質では加秢とともに漸増するが，乳頭部で は50歳代までいったん漸減し, その後増加を示し た.この脂質の態度は AMPS 含量と鏡像的であ る (Fig. 3 ).

堅乳頭部 AMPS の分画：乳頭部の AMPS の組 成を検討するとFig. 4 のごとくなり，加粭ととも に変化する.変化の主要な分画はヒアルロン酸 (HA) である. 一方デルマタン硫酸 (DS), ヘパ ラン硫酸 (HS), コンドロイチン硫酸 $\mathrm{A}$ およびC

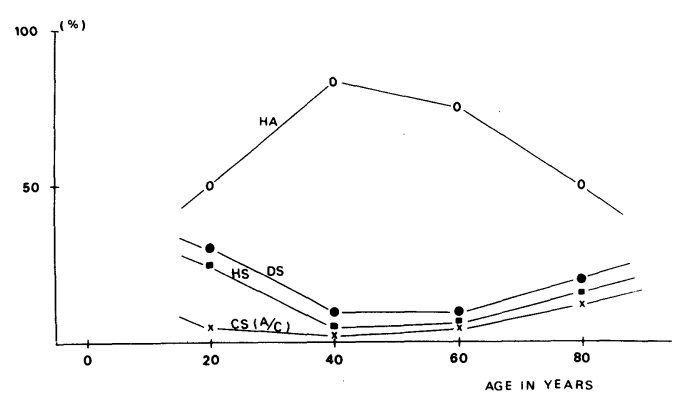

Fig. 4 Age-Related Change in AMPS Pattern of Renal Papilla

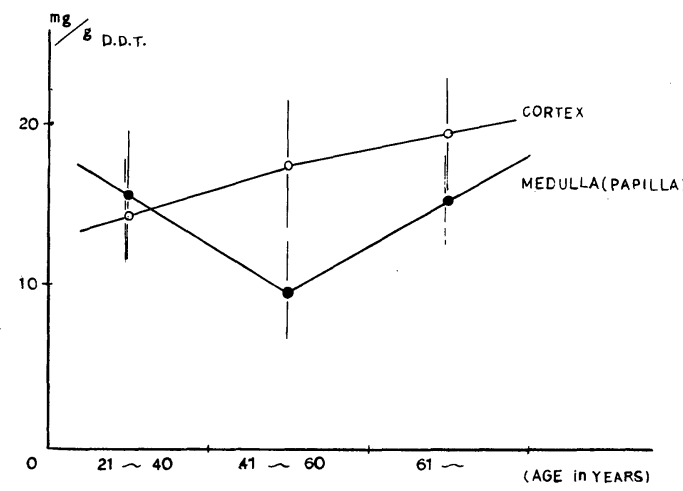

Fig. 3 Total Cholesterol Content of Human Kidney

$[\mathrm{CS}(\mathrm{A} / \mathrm{C})]$ はほぼ平行して加㱓とともに変化し， 主として50歳代以降増加してくる. しかし成分的 にはDSとHS が多い。

腎乳頭部の AMPS 分画と脂質 : AMPS と脂質 の対応をみると，HAに対して負の，一方 DS に 対して正の相関が得られた（ともに $\mathrm{p}<0.05)$.

\section{討 論}

腎䯣質，乳頭部 AMPS の機能的意義について は，現在まだ明らかでないことが多いが，尿濃縮 機構に関与している可能性が考えられている.わ れわれは，脱水時や各種の腎疾患時に AMPS が 特異的に変化する事実を観察しており，老年者の 水・電解質代謝異常の一因ともなると考えている.

腎の脂質代謝については，従来から，燐脂質が 皮質に多いことが知られて和り，燐脂質は膜の構 成成分として電解質の active transport に関連 しているといわれる. コレステロールや中性脂肪 についての分析報告は多いが，その機能的意義は 明らかでなく，また腎に执いて合成される可能性 も不明である。

最近, Hellström ら"1)，腎がコレステロール の前駆物質であるメバロン酸の代謝に関連する事 実を報告している。

以上のような従来の成績からみると，腎の脂質， とくにコレステロールや中性脂肪は血漿成分に由 来する可能性が大きいと考元られるが，今回われ われの観察した AMPS と脂質の関連性が，血管 壁のこれらの物質の動きのモデルとなりらるかど らかについては，まだ問題が残される．ただ腎乳 
腎動脈および腎乳頭部における酸性ムコ多糖と脂質含量の年齢的変化

頭部の AMPSの含量の多い点からは, AMPS の 機能を検索する上で有用であろらと判断される. とくにHAの多い点は, 他の組織と比較して特徵 的である.

われわれの成績は，HA が DS に比較してリポ， 蛋白との結合力が弱いという Iverius の成績を支 持しており,さらに脂質沈着に関して DS に促進 効果が, HA には抑制効果の存在する可能性を示 唆しているが, これらの機構の詳細については, 今後の検討を要する。

\section{結 論}

動脈壁の脂質沈着に果たす AMPS の役割を明 らかにするため, 腎動脈主幹部と, 血管以外の部 分で AMPS 含量の多い腎髄質 (乳頭部) に括い て, AMPS の総含量, 分画と, 脂質, とくに総 コレステロールとの対応を検討した。腎動脈にお いては, AMPS と脂質とは加龄とともに平行し
て漸増するが，腎乳頭部においては総コレストロ ールに対して HA は負に, DS は正の相関を示し て増減した。

\section{文献}

1) Crouse, J.R., Grundy, S.M. \& Ahrens, E.H. Jr. : Cholesterol Distribution in the Bulk Tissue of Man: Variation with Age. J. Clin. Invest., $51: 1292$ (1972).

2) Adams, C.W.M. and Bayliss, O.B. : Acid Mucosubstances Underlying Lipid Deposits in Ageing Tendons and Atherosclerotic Arteries. Atherosclerosis, $18: 191$ (1973).

3) Iverius, P.H. : The Interaction Between Human Plasma Lipoproteins and Connective Tissue Glycosaminoglycans. J. Biol. Chem., 247 : 2607 (1972).

4) Hellström, K.H., Siperstein, M.D., Bricker, L.A. and Luby, L.J. : Studies of the In Vivo Metabolism of Mevalonic Acid in the Normal Rat. J. Clin. Invest., 52 : 1303 (1973).

\section{質問 村田克己 (東大物療内科)}

1) Sulfated, non-sulfated AGAG の分画法に ついて.

2) Individual AGAGの定量法について.

3) Cholesterol 含量と sulfated AGAGの相関 意義をどのように考えて抢られるか。以上の点に ついて抏教え下さい。

\section{回答 井上剛輔}

1) 硫酸化したムコ多糖と非硫酸化のそれとの 分画は, Dowex 1-X2 カラムにより分離したもの を, さらに畑, 永井らの 2 次元電気泳動法により チェックする方法をとっています.

2) ヒアルロン酸の減少と，コレステロールの 沈着との関係は, 腎髄質の酸性ムコ多糖の含量に, ヒアルロン酸が比較的多いことから，負の相関が より強く印象つけりれています。腎髄質のヒアル ロン酸の機能については，な扣検討を要すると思 います。

質問 金子 仁 (日本医大・老研基礎部)

1) 乳頭部の酸性ムコ多糖の含有量の比較を年 齢を基準として分けて未られるが，例えば D.M.
の場合は乳頭部に変性壊死が起こるので D.M. な どを除外しないとデーターの比較はできないと思 います。

2）乳頭部の脂質にしても，中毒死の場合は尿 細管の脂肪変性が起こる場合があります。したが ってこのような例も除外せねばならないと思いま す.

\section{回答 井上剛輔}

1) 東京都監察医務院の材料なので, 死因につ き問題が残りますが，剖検時の成績も参考にさせ て戴き, 可及的に新鮮例を, また, 腎疾患, 特殊 な疾患例を除外しています。

2 ）糖尿病例は, 今回含めておりません。糖尿 病例は, 別に教室例につき検討し, 糖尿病学会に 報告しております。糖尿病例の腎髄質酸性ムコ多 糖は，系球体腎炎例に比べ，低下しており，イン スリンとの関与なども考劣て打ります.

3）腎疾患，とくにネフローゼ症候群時などに は, 脂肪代謝が変わり，また腎の含量も（脂質） 変化すると考学られますので，このよらな病的状 態については，今後検討したいと思います。 


\title{
Summary
}

\section{Age-related Change in Glycosaminoglycans and Lipids Contents in Artery and Papilla of Human Kidney}

\author{
Gosuke InOUE, Terufumi SAwADA, Hyoei YASUdA and Masaki YoshIKAWA \\ Department of Geriatrics, Faculty of Medicine, University of Tokyo
}

In the genesis of atherosclerosis, the deposition of lipids in the arterial wall seems crucial. Acid Mucopolysaccharides (AMPS, glycosaminoglycans) are assumed to be involved in this lipids precipitation process. Recent studies suggest that the analyses of interstitial substances of many different tissues besides artery may be valuable to elucidate the atherogenetic process.

In man, AMPS content of the renal papilla is rich and comparable to that for the aorta, which seems to justify a detailed study on AMPS and lipids content of the renal papilla with age.

20 human kidneys of various ages from 1 to 78 were obtained at post mortem examination 4-12 hr after death. None of the kidney used were involved by any evident disease process except nephrosclerosis. The main renal artery and papillary region were removed and analysed for AMPS and lipids (total cholesterol and phospholipids).

In the artery, AMPS and lipids levels increased with age. But in the papilla, AMPS increased during first five decades and decreased thereafter, while cholesterol content decreased until 50 years, followed by an increase.

Analysis of AMPS composition suggests that not only dermatan sulfate facilitates, but also hyaluronic acid might prevent the lipid precipitation in the renal papilla.

Key words : Acid Mucopolysaccharides (glycosaminoglycans), Cholesterol, Renal Papilla, Renal Artery, Age 